\title{
TINJAUAN YURIDIS TERHADAP KEPUTUSAN REKTOR NOMOR 067/UN55/PR.05/2018 TENTANG PENYESUAIAN UANG KULIAH TUNGGAL DI UNIVERSITAS SULAWESI BARAT
}

Oleh:

\author{
St.Hartina
}

Dr. Putera Astomo, SH.,MH

Dian Fitri Sabrina, SH.,MH.

Email: st.hartina@gmail.com

\begin{abstract}
Abstrak
Universitas Sulawesi Barat sebagai salah satu Universitas yang berada dalam lingkungan Kemenristekdikti berdasarkan Permenristekdikti Nomor 80 Tahun 2017 tentang Statuta Universitas Sulawesi Barat. Rektor Universitas Sulawesi Barat mengeluarkan Surat Keputusan Rektor Nomor 067/UN55/PR.05/2018 tentang Penetapan Penyesuaian Uang Kuliah Tunggal di Lingkungan Universitas Sulawesi Barat Tahun Angkatan 2016 Tahun Akademik 2018/2019 dengan mengacu langsung kepada Permenristekdikti No. 39 Tahun 2016 oleh karena Universitas Sulawesi Barat tidak memiliki Praturan Rektor yang mengatur tentang UKT dan BKT di lingkungan Universitas Sulawesi Barat.
\end{abstract}

\section{Kata Kunci: Tinjauan Yuridis, Surat Keputusan Rektor, Uang Kuliah Tunggal}

\section{A. Latar Belakang Masalah}

Pendidikan merupakan aspek yang sangat penting dari pelaksanaan hak-hak asasi manusia, penyelenggaraan tersebut dilakukan setiap negara demi mencapai cita-cita nasional dan tujuan negara yang bersangkutan. Indonesia termasuk salah satu negara yang mengakui dan melindungi hak asasi manusia di bidang pendidikan dibuktikan dengan dimuatnya dalam konstitusi negara Indonesia yaitu dalam Undang-Undang Dasar Negara Republik Indonesia tahun 1945 (UUD NRI Tahun 1945) yang tertulis pada alinea ke empat Pembukaan UUD NRI Tahun 1945 pada kalimat "mencerdaskan kehidupan bangsa". Pasal 31 ayat (1) UUD NRI Tahun 1945 yang berbunyi bahwa setiap warga negara berhak mendapat pendidikan, selanjutnya dalam ayat (3) yang berbunyi bahwa pemerintah mengusahakan dan menyelenggarakan suatu sistem pendidikan nasional yang meningkatkan keimanan dan ketakwaan serta akhlak mulia dalam rangka mencerdaskan kehidupan bangsa yang diatur dengan undang-undang.

Amanat konstitusi tersebut ditindak lanjuti dengan pembentukan berbagai peraturan perundang-undangan di bidang pendidikan meliputi UU No. 20 Tahun 2003 Tentang Sistem Pendidikan Nasional dan UU No. 12 Tahun 2012 Tentang Pendidikan Tinggi. ${ }^{1}$

\footnotetext{
${ }^{1}$ Rianti, 2011, “Kajian Yuridis Tentang Keberadaan Perguruan Tinggi Negeri Badan Hukum Milik Negara Dalam Undang-Undang Sistem Pendidikan Nasional", DIH Jurnal Ilmu Hukum Universitas 17 Agustus 1945 Surabaya, Vol.7, No.13, hlm.2
} 
UU No. 12 Tahun 2012 tentang Pendidikan Tinggi. Berdasarkan UU tersebut, Perguruan Tinggi diberikan wewenang menjalankan otonomi perguruan tinggi sebagaimana disebutkan dalam Pasal 62 ayat (1) yang berbunyi bahwa "Perguruan tinggi memiliki otonomi untuk mengelola sendiri lembaganya sebagai pusat penyelenggaraan Tridharma”, ayat (2) berbunyi bahwa, “otonomi pengelolaan perguruan tinggi sebagaimana dimaksud pada ayat (1) dilaksanakan sesuai dengan dasar da tujuan serta kemampuan perguruan tinggi", ayat (3) berbunyi bahwa: "dasar dan tujuan serta kemampuan pergruan tinggi untuk melaksanakan otonomi sebagaimana dimaksud pada ayat (2) dievaluasi secara madiri oleh perguruan tinggi”.

Universitas Sulawesi Barat sebagai salah satu Universitas yang berada dalam lingkungan Kemenristekdikti berdasarkan Permenristekdikti Nomor 80 Tahun 2017 tentang Statuta Universitas Sulawesi Barat. Rektor Universitas Sulawesi Barat mengeluarkan Surat Keputusan Rektor Nomor 067/UN55/PR.05/2018 tentang Penetapan Penyesuaian Uang Kuliah Tunggal di Lingkungan Universitas Sulawesi Barat Tahun Angkatan 2016 Tahun Akademik 2018/2019 dengan mengacu langsung kepada Permenristekdikti No. 39 Tahun 2016 oleh karena Universitas Sulawesi Barat tidak memiliki Praturan Rektor yang mengatur tentang UKT dan BKT di lingkungan Universitas Sulawesi Barat.

Berdasarkan uraian kasus diatas, penulis melihat perlu dilakukan kajian secara yuridis terhadap Surat Keputusan Rektor Universitas Sulawesi Barat Nomor 067/UN55/PR.05/2018 tentang Penetapan Penyesuaian Uang Kuliah Tunggal di Lingkungan Universitas Sulawesi Barat Tahun Angkatan 2016 Tahun Akademik 2018/2019.

\section{B. Rumusan Masalah}

1. Apakah Surat Keputusan Rektor Universitas Sulawesi Barat Nomor 067/UN55/PR.05/2018 tentang Penetapan Penyesuaian Uang Kuliah Tunggal di Lingkungan Universitas Sulawesi Barat Tahun Angkatan 2016 telah sesuai dengan Permenristekdikti Nomor 39 Tahun 2016Tentang Biaya Kuliah Tunggal Dan Uang Kuliah Tunggal Pada Perguruan Tinggi Negeri di Lingkungan Kementerian Riset, Teknologi, Dan Pendidikan Tinggi?

2. Apakah Surat Keputusan Rektor Nomor 067/UN55/PR.05/2018 tentang Penetapan Penyesuaian Uang Kuliah Tunggal di Lingkungan Universitas Sulawesi Barat tahun Angkatan 2016 dapat diberlakukan pada Semester Ganjil tahun Akademik 2018/2019? 


\section{Hasil Penelitian dan Pembahasan}

\section{Hasil Penelitian}

Universitas Sulawesi Barat merupakan Perguruan Tinggi (PT) yang berada di Kabupaten Majene, Sulawesi Barat. Universitas ini didirikan pada tanggal 19 Februari 2011, yang di Pimpin oleh Rektor Dr. Ir. Akhsan Djalaluddin Ms selama dua periode hingga sekarang, yang berlokas di Jln. Prof. Dr. Baharuddin Lopa SH, Talumung, Majene, Sulawesi Barat, Indonesia. 19 Februari 2011 merupakan tonggak sejarah berdirinya Universitas Sulawesi Barat sebagai Perguruan Tinggi Negeri (PTN). Proses pendiriannya ditandai dengan pendirian Yayasan Pendidikan Indonesia Sulawesi Barat sebagai wadah pendirian Universitas Sulawesi Barat.

Pendirian Universitas Sulawesi Barat ditandai dengan dikeluarkannya Peraturan Presiden Republik Indonesia Nomor 36 Tahun 2013 Tentang Pendirian Universitas Sulawesi Barat. Universitas Sulawesi Barat sebagai PTN diatur dengan Peraturan Menteri Riset Teknologi dan Pendidikan Tinggi No. 8 Tahun 2017 Tentang Statuta Universitas Sulawesi Barat dan Peraturan Menteri Riset, Teknologi, Dan Pendidikan Tinggi Republik Indonesia Nomor 41 Tahun 2017 Tentang Organisasi dan Tata Kerja Universitas Sulawesi Barat.

Pada 30 Juli 2019 Aliansi mahasiswa Fakultas Ilmu Sosial dan Ilmu Politik menggelar aksi unjuk rasa dengan menuntut penurunan UKT mahasiswa karena dianggap tidak sesuai dengan kondisi keuangan mahasiswa. Kemudian seling empat hari, pada 03 Agustus 2018 Pimpinan Universitas Sulawesi Barat menjawab aksi unjuk rasa tersebut dengan mengeluarkan Surat Keputusan Rektor Nomor 067/UN55/PR.05/2018 tentang Penetapan Penyesuaian Uang Kuliah Tunggal di Lingkungan Universitas Sulawesi Barat Tahun Angkatan 2016 Tahun Akademik 2018/2019.

\section{Pembahasan}

a. Kesesuaian Surat Keputusan Rektor Universitas Sulawesi Barat Nomor 067/UN55/PR.05/2018 tentang Penetapan Penyesuaian Uang Kuliah Tunggal di Lingkungan Universitas Sulawesi Barat Tahun Angkatan 2016 dengan Permenristekdikti Nomor 39 Tahun 2016 Tentang Biaya Kuliah Tunggal Dan Uang Kuliah Tunggal Pada Perguruan Tinggi Negeri di Lingkungan Kementerian Riset, Teknologi, Dan Pendidikan Tinggi. 
Berdasarkan Pasal 2 Peraturan Menteri Riset Teknologi dan Pendidikan Tinggi (Permenristekdikti) Nomor 39 Tahun 2016, Biaya Kuliah Tunggal (BKT) adalah keseluruhan biaya operasional yang terkait langsung dengan proses pembelajaran mahasiswa per semester pada program studi di Perguruan Tinggi Negeri (PTN), sedangkan berdasarkan Pasal 3 Uang Kuliah Tunggal (UKT) adalah sebagian dari BKT yang ditanggung setiap mahasiswa berdasarkan kemampuan ekonominya dan diatur berdasarkan dengan Peraturan Menteri Riset Teknologi dan Pendidikan Tinggi, yang kemudian dikelompokkan sesuai dengan yang tercantum dalam Pasal 4 huruf d yang selanjutnya diatur dalam Pasal 5 ayat (3)

Universitas dapat menetapkan ulang pemberlakuan UKT terhadap mahasiswa berdasarkan Pasal 5 Permenristekdikti Nomor 39 Tahun 2016 yang berbunyi bahwa:

(1) Pimpinan PTN dapat melakukan penetapan ulang pemberlakuan UKT terhadap mahasiswa apabila terdapat:

a. ketidaksesuaian kemampuan ekonomi mahasiswa yang diajukan oleh mahasiswa, orangtua mahasiswa, atau pihak lain yang membiayainya.

b. pemutakhiran data kemampuan ekonomi mahasiswa, orangtua mahasiswa, atau pihk lain yang membiayainya.

(2) Ketentuan lebih lanjut mengenai penetapan ulang pemberlakuan UKT sebagaimana dimaksud pada ayat (1) diatur oleh Pimpinan $P T N$.

Universitas Sulawesi Barat telah melakukan penetapan ulang UKT dengan Surat Keputusan Rektor Nomor 067/UN55/PR.05/2018 tentang Penetapan Penyesuaian Uang Kuliah Tunggal di Lingkungan Universitas Sulawesi Barat Tahun Angkatan 2016 Tahun Akademik 2018/2019 yang merupakan salah satu produk keputusan (Beschikking) yang dikeluarkan oleh pejabat publik di lingkungan Universitas Sulawesi Barat.

Menurut Muchsan, (Beschikking) adalah penetapan tertulis yang diproduksi oleh pejabat Tata Usaha Negara yang mendasarkan diri pada peraturan perundang-undangan yang berlaku, bersifat konkrit, individual, dan final. ${ }^{2} \mathrm{Hal}$ ini senada dengan yang tercantum dalam Pasal 1 angka 3 UU No.5 Tahun 1986 tentang Peradilan Tata Usaha Negara yang berbunyi bahwa:

\footnotetext{
${ }^{2}$ Muchsan , 1982,Pengantar Hukum Adinistrasi Negara Indonesia (Alrushd Bookstore), Yogyakarta,Liberty Yogyakarta, hal 54.
} 
"Keputusan Tata Usaha Negara adalah suatu penetapan tertulis yang dikeluarkan oleh Badan atau Pejabat Tata Usaha Negara yang berisi Tindakan Hukum Tata Usaha Negara berdasarkan peraturan perundang-undangan yang berlaku, yang bersifat konkrit, individual, dan final, yang menimbulkan akibat hukum bagi seseorang atau badan hukum perdata”.

Pejabat publik dalam hal ini Rektor Universitas Sulawesi Barat mendapatkan wewenang untuk mengeluarkan keputusan tersebut yang berasal dari atribusi, yakni dari Permenristekdikti Nomor 80 Tahun 2017 sebagaimana dikatakan oleh Ridwan HR bahwa wewenangan yang diperoleh secara atribusi bersifat asli berasal dari peraturan perundang-undangan. ${ }^{3}$ Surat Keputusan Rektor Nomor 067/UN55/PR.05/2018 yang dikeluarkan pejabat publik Universitas Sulawesi Barat tidak mengacu kepada Permenristekdikti Nomor 39 Tahun 2016, hal ini dibuktikan dengan tidak dicantumkannya Permenristekdikti Nomor 39 Tahun 2016 dalam konsiderang Surat Keputusan Rektor tersebut, baik dalam bagian menimbang maupun mengingat.

Jika dalam konsiderang Surat Keputusan Rektor No.067/UN55/PR.05/2018 dicantumkan Permenristekdikti Nomor 39 Tahun 2016 penulis kembali mendapatkan adanya ketidaksesuaian antara Surat Keputusan Rektor dengan Permenristekdikti, yakni pada Pasal 3 yang berbunyi:

Pasa 3 ayat (1)

UKT sebagaimana dimaksud dalam Pasal 2 ayat (2) terdiri atas beberapa kelompok yang ditentukan berdasarkan kemampuan ekonomi mahasiswa, orang tua mahasiswa, atau pihak lain yang membiayainya.

Pasal 3 (2)

Pengelompokan sebagaimana dimaksud pada ayat (1) diusulkan oleh PTN kepada Menteri untuk ditetapkan.

Kemudian dalam Pasal 6 yang berbunyi bahwa:

Pasal 6 (1)

Pemimpin PTN dapat melakukans penetapan ulang pemberlakuan UKT terhadap mahasiswa apabila terdapat:

a. ketidaksesuaian kemampuan ekonomi mahasiswa yang diajukan oleh mahasiswa, orang tua mahasiswa, atau pihak lain yang membiayainya; dan/atau

\footnotetext{
${ }^{3}$ Ridwan HR,2016,Hukum Administrasi Negara,Jakarta,Rajawali Pers, hlm 105.
} 
b. pemutakhiran data kemampuan ekonomi mahasiswa, orang tua mahasiswa, atau pihak lain yang membiayainya.

Pasal 6 ayat (2)

Ketentuan lebih lanjut mengenai penetapan ulang pemberlakuan UKT sebagaimana dimaksud pada ayat (1) diatur oleh Pemimpin PTN.

Isi Surat Keputusan yang dikeluarkan oleh pimpinan Universitas Sulawesi Barat mengatur tentang penurunan UKT mahasiswa Tahun Angkatan 2018/2019 Tahun Akademik 2016 dengan spesifikasi penurunan saintek dari UKT tertinggi senilai Rp 2.400.000,- sampai terendahsenlai $\mathrm{Rp} 1.200 .000,-$ menjadi $\mathrm{Rp}$ 1.200.000,-. Kemudian untuk Sosum dari UKT tertinggi senilai Rp 2.000.000,dan terendah senilai Rp 1.000.000.- menjadi Rp 1.000.000,-. Dengan kata lain, SK tersebut menyamaratakan penurunan tanpa mempertimbangkan aspek keadilan dan bunyi frasa "ditentukan berdasarkan kemampuan ekonomi mahasiswa, orang tua mahasiswa, atau pihak lain yang membiayainya" dalam Permenristekdikti Nomor 39 tahun 2016.

Menurut, Aristoteles keadilan adalah kebajikan yang berkaitan dengan hubungan antar manusia. Adil dapat berarti menurut hukum dan apa yang sebanding, yaitu yang semestinya. Memiliki nilai yang sama belum tentu adil dalam konsep kebutuhan. ${ }^{4}$ Dalam kaitannya dengan frasa "ditentukan berdasarkan kemampuan ekonomi mahasiswa, orang tua mahasiswa, atau pihak lain yang membiayainya" penulis melihat adanya penyimpangan dari konsep keadilan itu sendiri.

Berdasarkan uraian diatas, penulis menyimpulkan bahwa Surat Keputusan Rektor Universitas Sulawesi Barat Nomor 067/UN55/PR.05/2018 tidak sesuai dengan Permenristekdikti Nomor 39 Tahun 2016, hal tersebut ditandai dengan adanya ketidak sesuaian antara UKT yang terdapat pada lampiran IV Permenristekdikti Nomor 39 Tahun 2016 dengan UKT yang ditetapkan Universitas Sulawesi Barat, bahkan ndalam konsiderang Permenristekdikti No.39 Tahun 2016 tidak dicantumkan.

Terdapat peraturan yang dicantumkan dalam konsiderang Surat Keputusan Rektor yang penulis anggap “kabur” atau “tidak jelas” atau “Obscur libel" karena tidak memiliki keterangan yang jelas aturan yang dicantumkan

\footnotetext{
${ }^{4}$ R Soeroso, 2014, Pengantar Ilmu Hukum, Jakarta: Sinar Grafika, hlm 63
} 
mengatur tentang apa sehingga mempengaruhi nilai dari Surat Keputusan Rektor tersebut, aturan tersebut adalah:

1. Undang-Undang Nomor 20 Tahun 2002 Tentang Pendidikan Nasional (Lembaran Negara Nomor 78 Tahun 2002). Peraturan ini dianggap “tidak jelas” atau “obscur libel” karena penetapan Pendidikan Nasional mengatur tentang pendidikan secara nasional yang tidak menyertakan lagi Perguruan Tinggi didalamnya sejak dikleuarkannya Undang-Undang Nomor 12 Tahun 2012 tentang Pendidikan Tinggi. Undang-undang ini juga tidak mengatur tengtang tarif dan penetapan UKT, maka penulis melihat adanya "ketidak jelasan” atau “obscur libel” atas dicantumkannya undang-undang ini dalam konsiderang.

2. Peraturan Presiden Nomor 23 Tahun 1956 Tentang Pendirian Universitas Hasanuddin (Lembaran Negara Nomor 39 Tahun 1956. Peraturan ini dianggap “tidak jelas” atau “obscur libel” karena Peraturan Presiden tentang pendirian Universitas Hasanuddin merupakan institusi lain diluar Universitas Sulawesi Barat yang tidak ada kaitannya dengan penetapan ulang UKT di Universitas Sulawesi Barat.

3. Peraturan Presiden Nomor 66 Tahun 2010 Tentang Pengesahan Protokol untuk Melaksanakan Paket ke enam Komitmen Jasa Angkutan Udara dalam Persetujuan Kerangka Kerja ASEAN di Bidang Jasa (lembaran Negara Nomor122 Tahun 2010). Peratuan ini dianggap "tidak jelas" atau “obscur libel" karena peraturan ini tidak mengatur dan tidak memiliki kaitan sama sekali dengan isi dari putusan yakni penetapan ulang UKT di Universitas Sulawesi Barat.

4. Peraturan Menteri Riset Teknologi dan Pendidikan Tinggi RI Nomor 41 Tahun 2017 Tentang Organisasi dan Tata Kerja Kementerian Riset teknologi dan Pendidikan Tinggi (Berita Negara Nomor 805 Tahun 2017). Peraturan “tidak jelas” atau "obscur libel” karena Surat Keputusan Rektor Universitas Sulawesi Barat merupakan produk beschikking dari pejabat publik di lingkup Universitas Sulawesi Barat yang seharusnya mengacu kepada Organisasi dan Tata Kerja Uversitas Sulawesi Barat sebagai Instansi pembuat keputusan. Penetapan ulang UKT di Universitas Sulawesi Barat bukan wewenang dari Kemenristekdikti. 
Olehnya terdapat sesuatu yang tidak jelas dalam konsiderang maka unsur konkret tidak terpenuhi. Surat Keputusan Rektor yang mencantumkan aturanaturan yang tidak jelas dalam konsiderang merupakan suatu bukti bahwa Surat Keputusan Rektor tersebut tidaklah konkret melainkan. Olehnya penulis menyimpulkan bahwa Surat Keputusan Rektor tersebut “cacat hukum" atau "batal demi hukum (null and void)" sebagaimana A.M. Donner mengemukakan akibat-akibat dari keputusan yang tidak sah yaitu keputusan itu harus dianggap batal sama sekali dan berlakunya keputusan itu dapat digugat. ${ }^{5}$

b. Pemberlakuan Surat Keputusan Rektor Nomor 067/UN55/PR.05/2018 tentang Penetapan Penyesuaian Uang Kuliah Tunggal di Lingkungan Universitas Sulawesi Barat Tahun Angkatan 2016 Tahun Akademik 2018/2019

Berdasarkan data yang diperoleh penulis, dalam Kalender Akademik Universitas Sulawesi Barat Tahun Akademik 2018-2019 pembayaran UKT diluar mahasiswa baru dijadwalkan tanggal 17 Juli - 03 Agustus 2018. Surat Keputusan Rektor Nomor 067/UN55/PR.05/2018 tentang penetapan ulang UKT dikeluarkan pada 03 Agustus 2018, atau di hari terakhir jadwal pembayaran UKT semester ganjil Tahun Akademik 2018-2019. ${ }^{6}$

Dalam Hukum Tata Negara (HTN) dikenal bahwa suatu aturan yang telah ditetapkan berlaku sejak peraturan itu ditetapkan dan berlaku pula untuk peristiwa setelah peraturan itu ditetapkan, bukan untuk peristiwa yang telah lampau. Selain itu dalam konsiderang Surat Keputusan juga terdapat frasa dalam keputusan yang keenam yang berbunyi "Surat keputusan ini mulai berlaku pada tanggal ditetapkan dengan ketentuan bahwa apabila dikemudian hari terdapat kekeliruan dalam surat keputusan ini akan diadakan perbaikan sebagaimana mestinya”.

Seperti yang dimaksud dengan asas legalitas yang dijunjung tinggi oleh setiap negara yang menyebut dirinya sebagai negara hukum. Legalitas adalah asas pokok dalam negara hukum selain asas perlindungan kebebasan dan Hak Asasi Manusia. Di Indonesia, asas legalitas bersandar pada Pasal 1 ayat (3) UUD NRI Tahun 1945 yang berbunyi bahwa:

\footnotetext{
${ }^{5}$ Samgeri Ezra Repi, 2016, "Tinjauan Yuridis tentang Sah atau Tidaknya Suatu Keputusan Administrasi Pemerintahan (Beschikking)", Jurnal Lex Crimen, Vo.V, No.4. hlm 163.

${ }^{6}$ Kalender Akademik Universits Sulawesi Barat Tahun Akademik 2018-2019. Tanggal 04 Juli 2018.
} 
"Negara Indonesia adalah negara hukum".

Selama ini asas legalitas memang lebih dikenal dalam hukum pidana, yang ditarik dalam rumusan Pasal 1 ayat (1) Kitab Undang-Undang Hukum Pidana yang berbunyi bahwa: "tiada suatu perbuatan yang dapat dihukum kecuali berdasarkan ketentuan pidana menurut undang-undang yang telah ada terlebih dahulu daripada perbuatannya itu sendiri”. Namun, asas legalitas juga dikenal dalam Hukum Administrasi Negara (HAN) dengan istilah wetmatigheid van het berstuur yang mengandung arti setiap tindakan pemerintahan harus ada dasar hukumnya dalam suatu peraturan perundang-undangan. Asas ini dapat dilihat pada Pasal 1 angka 8 UU No.51 Tahun 2009 tentang Perubahan Kedua atas UU No.5 Tahun 1986 tentang Peradilan Tata Usaha Negara yang berbunyi bahwa:

"Badan atau Pejabat Tata Usaha Negara adalah badan atau pejabat yang melaksanakan urusan pemerintahan berdasarkan peraturan perundang-perundang yang berlaku”.

Menurut Indroharto dalam bukunya Usaha Memahami Undang-Undang tentang Pradilan Tata Usaha Negara, semula asas legalitas dalam konteks HAN/HTN hanya berkaitan dengan usaha melawan hak raja-raja untuk memungut pajak dari rakyat kalau rakyat tidak diwakili dalam badan perwakilan. Sekarang, pengertian asas itu meluas hingga tentang semua wewenang dari aparat pemerintah yang melanggar kebebasan atau hak milik warga masyarakat di tingkat manapun. Dengan asas legalitas berarti tanpa adanya dasar wewenang yang berlaku, maka aparat pemerintah tidak memiliki wewenang yang dapat mempengaruhi atau atau mengubah keadaan posisi hukumwarga masyarakat. ${ }^{7}$

Asas legalitas juga secara tegas disebutkan dalam Pasal 5 UU No.30 Tahun 2014 tentang Administrasi Pemerintahan yang berbunyi bahwa:

"Penyelenggaraan Administrasi Pemerintahan berdasarkan:1. Asas Pemerintahan....".

Berdasarkan uraian diatas, dapat disimpulkan bahwa asas legalitas mengandung arti bahwa penyelenggaraan pemerintahan mengedepankan dasar hukum dari sebuah keputusan dan/atau tindakan yang dibuat oleh badan

\footnotetext{
${ }^{7}$ http//.hukum online.com/klinik/detail/ulasan/c16986/makna-asas-legaltas-dalam-hukum-administrasinegaraa/ diakses pada 07 Mei 2019 Pukul 22.03 Wita.
} 
atau/pejabat pemerintahan dengan konsekuensi keputusan atau tindakan badan atau pejabat pemerintahan tidak bisa dilakukan semena-mena.

Dalam kaitannya dengan pembayaran UKT Universitas Sulawesi Barat yang dijadwalkan tanggal 17 Juli - 03 Agustus 2018 kemudian Surat Keputusan Rektor Nomor 067/UN55/PR.05/2018 tentang penetapan ulang UKT dikeluarkan pada 03 Agustus 2018, atau di hari terakhir jadwal pembayaran UKT semester ganjil Tahun Akademik 2018-2019. Surat Keputusan Rektor tersebut ditetapkan di hari terakhir jadwal pembayaran UKT. Dengan kata lain pembayaran UKT telah berjalan selama 18 hari.

Berdasarkan asas legalitas, Surat Keputusan Rektor Nomor 067/UN55/PR.05/2018 tidak dapat diberlakukan bagi mahasiswa yang melakukan pembayaran UKT sebelum Surat Keputusan Rektor tersebut dikeluarkan. Surat Keputusan Rektor Nomor 067/UN55/PR.05/2018 tidak dapat diberlakukan bagi mahasiswa semester ganjil Tahun Akademik 2018-2019 Tahun Angkatan 2016 secara menyeluruh berdasarkan asas legalitas yang berbunyi "Badan atau Pejabat Tata Usaha Negara adalah badan atau pejabat yang melaksanakan urusan pemerintahan berdasarkan peraturan perundang-perundang yang berlaku". Selain itu dalam konsiderang terdapat frasa "Surat keputusan ini mulai berlaku pada tanggal ditetapkan dengan ketentuan bahwa apabila dikemudian hari terdapat kekeliruan dalam surat keputusan ini akan diadakan perbaikan sebagaimana mestinya”.

Penerapan asas legalitas menurut Indroharto, akan menunjang berlakunya kepastian hukum dan kesaam perlakuan. Kesamaan perlakuan berlaku karena setiap orang berada dalam situasi seperti yang ditentukan dalam ketentuan undang-undang itu berhak dan berkewajiban untuk berbuat seperti apa yang ditentukan dalam undang-undang tersebut. Sementara itu kepastian hukum akan terjadi karena suatu peraturan dapat membuat semua tindakan yang akan dilakukan pemerintah itu dapat diramalkan atau diperkirakan terlebih dahulu dengan, dengan melihat kepada peraturan-peraturan yang berlaku. ${ }^{8}$

\section{Penutup}

\section{Kesimpulan}

\footnotetext{
${ }^{8}$ http//.hukum online.com/klinik/detail/ulasan/c16986/makna-asas-legaltas-dalam-hukum-administrasinegaraa/ diakses pada 07 Mei 2019 Pukul 22.03 Wita.
} 
a. Dalam konsiderang Surat Keputusan Rektor No.067/UN55/PR.05/2018 tentang Penetapan Penyesuaian Uang Kuliah Tunggal di Lingkungan Universitas Sulawesi Barat Tahun Angkatan 2016 Tahun Akademik 2018/2019 tidak sesuai dengan Permenristekdikti Nomor 39 Tahun 2016 tentang BKT dan UKT pada PTN di lingkungan Kemenristekdikti, hal tersebut ditandai dengan adanya ketidak sesuaian antara UKT yang terdapat pada lampiran IV Permenristekdikti Nomor 39 Tahun 2016 (sebagaimana terlampir) dengan UKT yang ditetapkan Universitas Sulawesi Barat. Dalam konsiderang Surat Keputusan Permenristekdikti Nomor 39 Tahun 2016 tidak. Juga terdapat peraturan yang dicantumkan dalam konsiderang Surat Keputusan Rektor yang "tidak jelas” atau “Obscur libel" maka penulis menyimpulkan bahwa Surat Keputusan Rektor tersebut “cacat hukum" atau dapat dikatakan "batal demi hukum".

b. Surat Keputusan Rektor Universitas Sulawesi Barat Nomor 067/UN55/PR.05/2018 tentang Penetapan Penyesuaian Uang Kuliah Tunggal di Lingkungan Universitas Sulawesi Barat Tahun Angkatan 2016 Tahun Akademik 2018/2019 dikeluarkan oleh pimpinan Universitas Sulawesi Barat pada 03 Agustus 2018. Dalam Kalender Akademik Universitas Sulawesi Barat Tahun Akademik 2018-2019 pembayaran UKT diluar mahasiswa baru dijadwalkan tanggal 17 Juli - 03 Agustus 2018. Surat Keputusan Rektor tersebut dikeluarkan di hari terakhir jadwal pembayaran UKT semester ganjil Tahun Akademik 20182019. Surat Keputusan Rektor tersebut tidak dapat diberlakukan bagi mahasiswa yang melakukan pembayaran UKT sebelum Surat Keputusan Rektor tersebut dikeluarkan. Surat Keputusan Rektor tersebut tidak dapat diberlakukan bagi mahasiswa semester ganjil Tahun Akademik 2018-2019 Tahun Angkatan 2016 secara menyeluruh berdasarkan asas legalitas yang berbunyi “Badan atau Pejabat Tata Usaha Negara adalah badan atau pejabat yang melaksanakan urusan pemerintahan berdasarkan peraturan perundang-perundang yang berlaku". Kemudan dalam konsiderang terdapat frasa "Surat keputusan ini mulai berlaku pasa tanggal ditetapkan dengan ketentuan bahwa apabila dikemudian hari terdapat kekeliruan dalam surat keputusan ini akan diadakan perbaikan sebagaimana mestinya”.

\section{Saran}


a. Pejabat publik Unversitas Sulawesi Barat dalam pengeluarkan Surat Keputusan seharusnya mengacu kepada peraturan perundang-undangan agar sifat final dan konkrit suatu keputusan dapat tercapai.

b. Dalam pengeluarkan Surat Keputusan, pejabat publik Universitas Sulawesi Barat hendaknya memperhatikan frasa "Surat keputusan ini mulai berlaku pada tanggal ditetapkan” dalam keputusan agar pemberlakuannya tidak menyalahi asas legalitas maupun peraturan yang ada.

\section{DAFTAR PUSTAKA}

\section{Bukun-buku :}

Muchsan , 1982,Pengantar Hukum Adinistrasi Negara Indonesia (Alrushd Bookstore), Yogyakarta,Liberty Yogyakarta.

Ridwan HR, 2016, Hukum Administrasi Negara, Jakarta, Rajawali Pers.

R Soeroso, 2014, Pengantar Ilmu Hukum, Jakarta: Sinar Grafika

\section{Peraturan Perundang-undangan :}

Undang-Undang Dasar Negara Republik Indonesia Tahun 1945.

Kitab Undang-Undang Hukum Pidana.

UU No. 20 Tahun 2003 Tentang Sistem Pendidikan Nasional (Tambahan Lembar Negara Nomor 4301 Tahun 2003)

UU No. 9 Tahun 2004 Tentang Peradilan Tata Usaha Negara (Lembar Negara Tahun 2004 No.35, Tambahan Lembar Negara 4380).

Undang-Undang No. 12 Tahun 2011 Tentang Pembentukan Peraturan Perundangundangan (Lembar Negara Tahun 2011 Nomor 82).

Undang-Undang No.12 Tahun 2012 Tentang Pendidikan Tinggi (Lembar Negara Tahun 2012 Nomor 158, Tambahan Lembar Negara Nomor 5336).

Peraturan Menteri Riset Teknologi dan Pendidikan Tinggi No.8 Tahun 2017 Tentang Statuta Universitas Sulawesi Barat (Berita Negara Nomor 1859 Tahun 2017).

Peraturan Menteri Riset, Teknologi, dan Pendidikan Tinggi Republik Indonesia Nomor 41 Tahun 2017 Tentang Organisasi dan Tata Kerja Universitas Sulawesi Barat (Berita Negara Tahun 2017 Nomor 805).

Peraturan Menteri Riset Teknologi dan Pendidikan Tinggi No.39 Tahun 2016 Tentang Biaya Kuliah Tunggal dan Uang Kuliah Tunggal (Berita Negara Tahun 2016 Nomor 1007). 
Peraturan Presiden Republik Indonesia Nomor 36 Tahun 2013 Tentang Pendirian Universitas Sulawesi Barat (Lembaran Negara Nomor 88 Tahun 2013).

Surat Keputusan Menteri Riset Teknologi dan Pendidikan Tinggi Nomor : 469/M/KPT.KP./2017 Tentang Perpanjangan Masa Jabatan Rektor Universitas Sulawesi Barat.

Surat Keputusan Rektor Nomor 067/UN55/PR.05/2018 tentang Penetapan Penyesuaian Uang Kuliah Tunggal di Lingkungan Universitas Sulawesi Barat Tahun Angkatan 2016 Tahun Akademik 2018/2019

\section{Lain-lain}

\section{Jurnal :}

Rianti, 2011, “Kajian Yuridis Tentang Keberadaan Perguruan Tinggi Negeri Badan Hukum Milik Negara Dalam Undang-Undang Sistem Pendidikan Nasional”, DIH Jurnal Ilmu Hukum Universitas 17 Agustus 1945 Surabaya, Vol.7, No.13

Samgeri Ezra Repi, 2016, “Tinjauan Yuridis tentang Sah atau Tidaknya Suatu Keputusan Administrasi Pemerintahan (Beschikking)", Jurnal Lex Crimen, Vo.5, No.4.

\section{Internet:}

http//.hukum online.com/klinik/detail/ulasan/c16986/makna-asas-legaltas-dalam-hukumadministrasi-negaraa/ diakses pada 07 Mei 2019 Pukul 22.03 Wita.

Kalender Akademik Universits Sulawesi Barat Tahun Akademik 2018-2019 